\title{
ADAPTION OF NOVEL APPROACH OF ONLINE TEACHING-LEARNING PROCESS DURING COVID-19 PANDEMIC AND DISCRIMINATION OF IT WITH CONVENTIONAL TEACHING LEARNING IN EDUCATION SYSTEM
}

\author{
Mayur M.Sevak \\ Research Scholar \\ Gujarat Technological University, Gujarat, India
}

\author{
Komal K.Shukla \\ Research Scholar \\ Sardar Patel University, Gujarat, India
}

\begin{abstract}
Change is the rule of nature, with this universal truth, success of any individual, mass or whole system is to adapt change in fast manner, learn from it and excel the same. Role of education is to nurture the lifelong learning approach into students along with their necessary skills and core values. After completion of any course of study, student will be able to develop his/her self for the outcomes of those courses. In this paper we have described the conventional teaching learning approach with novel approach of online teaching learning during Covid-19 pandemic lockdown. Each approach has its own advantages and disadvantages. According to the situation we can adapt novel approach with some rectification or conventional approach with advancements.
\end{abstract}

Keywords - Conventional teaching learning, On line eaching learning, Covid-19 pandemic, Zoom, Google Meet, Cisco Webex.

\section{INTRODUCTION}

In the current scenario of Covid-19 Pandemic the whole world is suffering from the uncertainty about future although there is vast and noticeable development in fields like Machine learning, Artificial Intelligence, Deep learning, Internet of Things and Internet of Everything. In this unexpected situation, most of the Covid-19 affected countries have implemented lockdowns that supports the prevention of spreading of Covid-19 viruses. As a result of lockdown industries, markets of selling products, Educational Institutions, Religious places etc. have been closed with reference to perticluar government circular for unexpected amount of time.

Role of Education is to mould the student with all type of knowledge that make him compatible to sustain in any situation. But most of the time its been seen that due to limitations on teaching side or learning side, students will not able to develop all the skill sets and as a result they will be projecting themselves towards job oriented education only instead of thinking about entrepreneurship and start ups.

Now if we think about the net effect of this Covid-19 pandemic lockdown on current education system than we see the tremendous change in teaching learning process. If we need to train the students as learned students with required knowledge and skill sets and outcomes than education system must not be affected by changing method of teaching.

Arora Amit et.al [4] studied impact of virtual classes and observed lack of awareness of adoption of virtual classroom, less attendance, lack of personal touch due to connectivity issues.

Veena Shenoy et al. [3] took sample of 20 faculties and observed that there was lots of resistance in teaching fraternity towards adapting new technology before Covid-19 but implementing novel approach of online teaching they found it more effective as compared to normal classrooms.

The rest of the paper is organized as follows. Conventional teaching learning approach with its advantages and dis advantages is explained in section II. Novel approach of Online teaching learning with its advantages and disadvantages is explained in section III. Concluding remarks are given in section IV.

\section{Convetninal Teching Learning Process}

Figure 1 shows the flow of conventional teaching learning process in which if we take example of any teacher or professor than first he is going to refer books, journals, articles or magazine before taking lecture. Teacher utilizes that knowledge to deliver lecture in class room with apparatus like chalk, marker, duster or PPT, Videos provided that there is facility of projector in classroom or lab. Students learn from that and preparing their lecture notes accordingly. Finally examination tests are going to decide the performance of particular student for that course. 


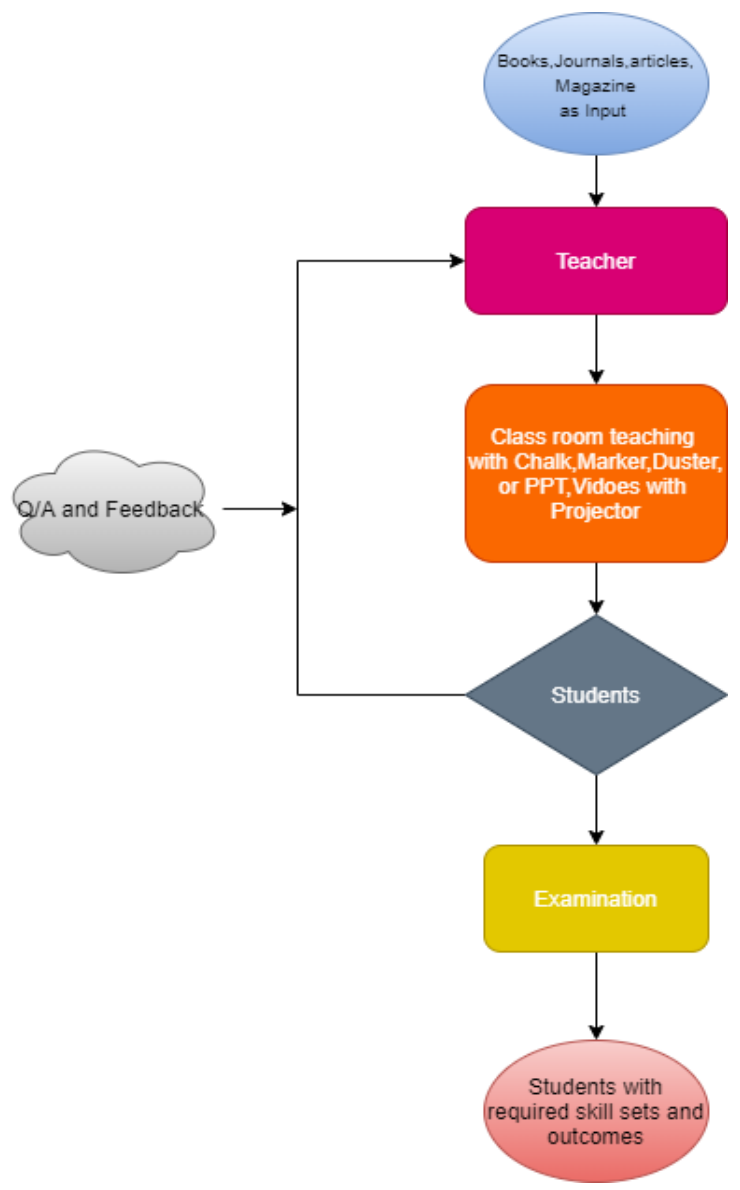

Fig. 1. Convetnional Teaching Learning Process

Conventional Teaching learning process has following advantages.

- Teacher is capable of maintaining harmony with students by keeping eye contacts.

- This method is technology independent

- Utilization of state of art infrastructure is adequate.

- Physical attendance of student is proved as he has attended the class with required concentration by reading his mindset.

- Teacher can take test and able to do invigilator duty so that examination conduction can be done with zero or minimum unfair means.

- Hands on experiment can be done on machines and other equipments for practical aspects.

- Assessment can be done with satisfactory level and result can be prepared accordingly.

Conventional Teaching Learning has following disadvantages.

- Targeted audience i.e. students, are limited as class seats are limited due to infrastructure.

- Fixed time slot of lecture is there according to time table prepared by institute.
- Lots of time, papers and other stationeries are used as conduction of examination ofline, assessment and result preparation.

\section{NOVEL APPROACH OF ONLINE TEACHING LEARNING PROCESS}

Figure 2 shows the flow of novel approach of online teaching learning process in which teacher prepares from various online sources available i.e. E-books, journals, magazines, articles etc. After that teacher is going for set up of online class room via various apps on desktops or mobile phones like Zoom, Google Meet, Cisco WebEx. Students are having question answers or feed back through corresponding apps only. Examination test can be conducted via different websites or apps or softwares.

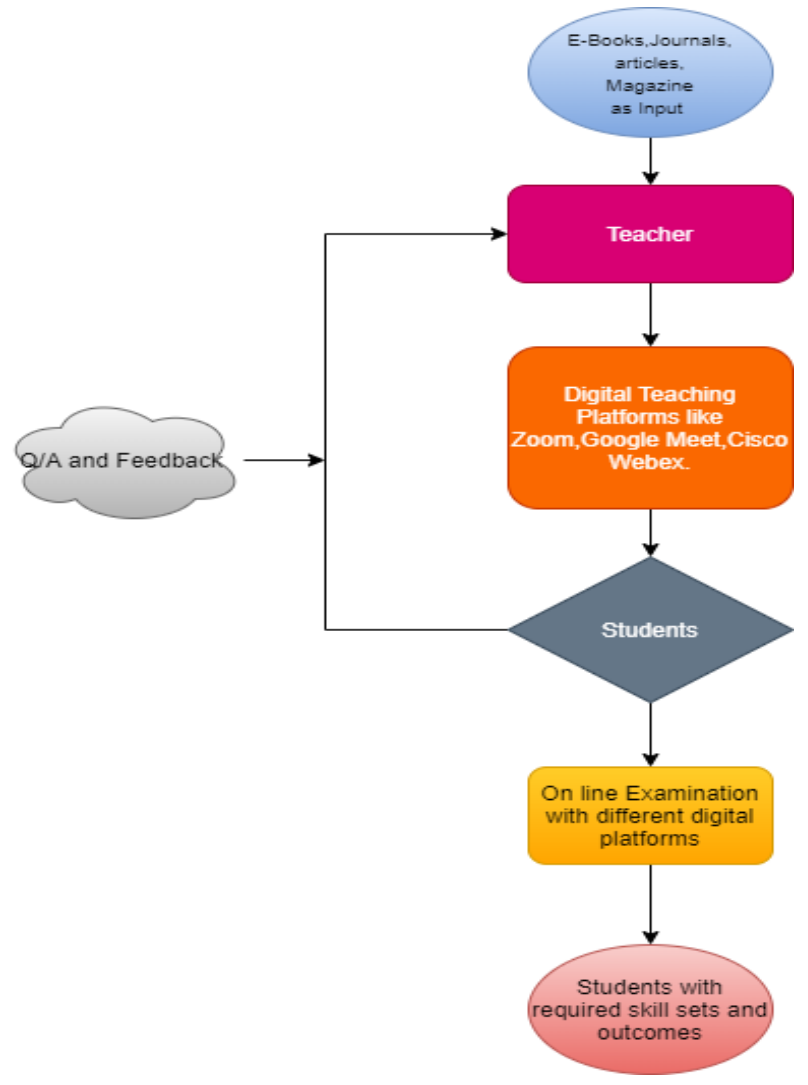

Fig 2. Novel Approach of Online Teaching learning process

Novel approach of Online Teaching learning process has following advantages.

- State of art digital apps are available for taking lectures.

- Timing flexibility of taking online lecture is more as compared to conventional teaching learning.

- No waste of paper and other resources as students are learning from their homes. 


\section{International Journal of Engineering Applied Sciences and Technology, 2020 \\ Vol. 5, Issue 2, ISSN No. 2455-2143, Pages 255-257 \\ Published Online June 2020 in IJEAST (http://www.ijeast.com)}

- There is no limitation of fixed number of students to attend lecture as there is no limitation due to infrastructure boundary.

- $\quad$ Recording facility is available throughout lecture so if student has missed any lecture due to some reason, he can refer it later on.

Novel approach of Online Teaching learning has following disadvantages.

- While online lecture is going on, if video camera of student is not on, one can't be sure about attendance of student.

- Hackers may disrupt ongoing lectures.

- If the examination is taken online then there must be appropriate arrangement that there will be no unfair means with help of internet and other sources

- If the speed of internet is slow on network or if it is rural area where there is no network coverage than student will not be able to attend online lectures.

- If device through which online lecture is taken, is malfunctioning then there is less possibility for online lecture conduction for that moment.

- Practical demonstration through software apps can be done but hands on with big machineries and equipments will not be possible with students.

\section{CONCLUSION}

Of Course, Covid-19 Pandemic has changed whole system from root to top level with sufficient transformation. Conventional teaching learning process has its own advantages and disadvantages with respect to novel approach of online teaching. According to improvement in further stages of lockdowns either conventional system can be implemented with corrective measure of social distancing and safety measures or novel approach can be implemented with adequate framework of security and other requirements.

\section{REFERENCE}

[1] Ghostasbpour F.,Swinnerton B., and Morris N(2020).Look who's talking:Exploring instuctors contribution to massive open online courses,British Journal of Education Technology,( pp. 228-244).

[2] Bower M.(2019).Technology mediated learning theory"British Journal of Educational Technology,(pp. 1035-1048).

[3] Shenoy V., Mahendra S., Vijay S.(2020),Covid-19 Lockdown technology adaption,teaching,learning,students engagement and facultyexperience,"Mukt Shabd Journal,(pp. 698-702).

[4] Arora A.,Shrinivasan R.(2020).Imapct of Pandemic Covid-19 on teaching learning process:A study of Higher Education Teachers,Prabandhan:Indian Journal of Management, DOI: 10.17010/pijom/2020/v13i4/151825

[5] Alqurashi, E. (2018). Predicting student satisfaction and perceived learning with online learning environments. Journal of Distance Education, 40(1),(pp.133-148).

[6] Eom, S. B., Wen, H. J., \& Ashill, N. (2006). The determinants of students' perceived learning outcomes and satisfaction in university online education: An empirical investigation. Decision Sciences Journal of Innovative Education, 4(2), (pp.215-235).

[7] Gaytan, J. (2015). Comparing faculty and student perceptions regarding factors that affect student retention in online education. American Journal of Distance Education, 29(1),(pp. 56-66).

[8] Osvaldo, R. C. (2012). MOOCs and the AI-Stanford like courses: Two successful and distinct course formats for massive open online courses. European Journal of Open, Distance and E-Learning. Retrieved from https://eric.ed.gov/?id=ej982976

[9] Prasad, P. D., Sunitha K.V.N., \& Rani, B. P. (2019). Factors affecting students continue intention to use MOOCs, benefits \& drawbacks. A research paper from the UAE context. International Journal of Innovative Technology and Exploring Engineering, 8(6S4), 763-769.

[10] Sprague, D., Maddux, C., Ferdig, R., \& Albion, P. (2007). Editorial : Online education : Issues and research questions. Journal of Technology and Teacher Education, 15(2), 157-166.

[11] Lone, A. Z. (2017). Impact of online education in India. IJESC, 7(7), 13050-13952.

[12] Shea, P., \& Bidjerano, T. (2009). Community of inquiry as a theoretical framework to foster "epistemic engagement" and "cognitive presence" in online education. Computers \& Education, 52(3), 543-553.

[13] https://zoom.us

[14] https://meet.google.com

[15] https://www.cisco.com 